\title{
Transnational Childhoods: The Participation of Children in Processes of Family Migration
}

\author{
MARJORIE FAULSTICH ORELLANA, Northwestern University \\ BARRIE THORNE, University of California, Berkeley \\ ANNA CHEE, California State University, Los Angeles \\ WAN SHUN EVA LAM, University of California, Berkeley
}

\begin{abstract}
Drawing upon ethnographic research in contemporary California, with case studies of migrants from Mexico, Central America, Korea, and Yemen, we analyze children's presence and participation in processes of migration and in the constitution of transnational social fields. Various facets of child-adult relations enter into children's movement across national borders, including their economic dependence and growing capacity to contribute labor; varied ways in which the needs and capacities of children of different ages and genders are defined; and their status as persons who are being "raised" and "developed" toward desired end points. These dimensions help shape patterns of chain and circulating migration; decisions about leaving children behind and sending for them; and the unusual circumstance of children who take the lead in migration (South Korean "parachute kids" living in suburban Los Angeles). "Sending children back" (or threatening to do so) is a deliberate strategy of child rearing used by transnational families. We consider how children help families stay connected across long distances, as well as the strains, conflicts, and emotional costs that may be involved. Children help constitute and reconfigure transnational social fields, and transnational practices, in turn, shape the contours of particular childhoods.
\end{abstract}

The case of Elián González (the five-year-old Cuban boy who was found floating in the Atlantic Ocean in November 1999 after a boat carrying him, his mother, and other migrants collapsed en route to the U.S.) sparked national attention to the movement of children across national borders. Elián's case was unusual, especially the way in which his "alien" presence was embraced and celebrated by much of the U.S. public. The attention it received helped to make visible children's various positions as "dependents" in families, as members of a social and legal age category, and as political actors with their own needs, rights, and desires. It also illuminated the complex issues that immigrant families face when they are divided across geopolitical borders, with children's futures potentially located in two or more places.

An earlier version of this paper was presented at the 14th World Congress of Sociology, Montreal Canada, July 1998. The research was sponsored and funded by the John D. and Catherine T. MacArthur Foundation Research Network on Successful Pathways through Middle Childhood with a grant administered through the Institute for Human Development at the University of California, Berkeley. For help in gathering and thinking about data in the Pico Union site, we would like to thank Lucila Ek and Arcelia Hernández; for their contributions to research in the Oakland site, our thanks to Nadine Chabrier, Ana González, Eileen Mears, Gladys Ocampo, Allison Pugh, and Hung Thai. We have also benefited from conversations with and comments from Catherine Cooper, Jill Denner, Marjorie Devault, Hanne Haavind, Pierrette HondagneuSotelo, Arlie Hochschild, Nazli Kibria, Jean Lave, John Modell, Susan Mahler, Nery Orellana, George Sanchez, Judith Stacey, Hung Thai, Diane Wolfe, and the editors and four anonymous reviewers from the journal Social Problems. Direct correspondence to: Marjorie Faulstich Orellana, School of Education and Public Policy, Northwestern University, Evanston IL 60208. The authors can also be contacted by e-mail: m-orellana@northwestern.edu; bthorne@socrates.berkeley.edu; achee@usc.edu; evalam@uclink4.berkeley.edu.

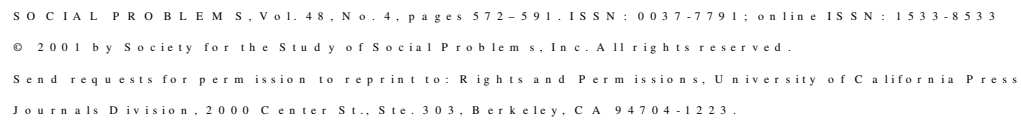


Most research on children and "the new immigration" avoids these complexities, focusing instead on children's trajectories within U.S. society. A growing literature on patterns of assimilation and biculturalism, children's health and educational attainment, and prospects for mobility of individuals and groups implicitly assumes that immigrant families have settled in the U.S. (e.g., García Coll and Magnuson 1997; Ogbu 1989; Portés and Zhou 1993; Rumbaut 1996; Zhou 1997a). But as some immigration scholars note, processes of settlement are often unstable. This may be especially true in an increasingly globalized world. New communication and transportation technologies make it easier to stay connected to homelands and to keep open the possibility of return. Shifting global economic and political conditions, with increased movement of labor and capital around the world (Sassen 1998) may make the future of some immigrant families more contingent and uncertain than in the past. This does not mean that families move easily through transnational circuits; on the contrary, the borders of nation-states are real, and they exert social, emotional, and financial costs on those who cross them (Hondagneu-Sotelo and Avila 1997).

During fieldwork in urban areas of California, we discovered families whose lives are deeply embedded in "transnational social fields"-a term introduced by Basch, Glick-Schiller, and Blanc (1994) for "multi-stranded social relations that link places of origin and settlement." As various ethnographers have demonstrated, transnational practices have become a habitual part of life for some immigrant groups (Garrison and Weiss 1979; Georges 1992; Guarnizo 1997; Guarnizo and Smith 1998; Mahler 1999; Olwig 1999; Rouse 1992). But these practices, and social fields, have mostly been studied with economic, labor, and political transactions at the forefront. Furthermore, research on the transnational family, household, and intimate relations assume that adults are the key social actors; children, with a few important exceptions (Olwig 1999; Soto 1987) are largely invisible. Our research aims to contribute to a small, but growing body of literature that highlights social and emotional relations organized in globalized spaces, and that looks at children as actors in the immigration process, and as "pivotal points" (Olwig 1999) in the construction of transnational social fields.

We anchor our work principally within the sociology and anthropology of childhoods (e.g., James and Prout 1997; Stephens 1995; Zelizer 1985), a line of theorizing and empirical research that grew out of Philippe Ariès' (1962) observation that childhood is not a "natural" phase of life or a given of biological age, but is socially constructed. Sociologists of childhood also seek to bring children's experiences and actions more fully into the study of society (Thorne 1987). Age divisions, like those of gender and "race," vary in organization and meaning; in different cultural and historical contexts, there may be different assumptions about the needs, capacities, and appropriate activities of children of different ages. Child-rearing practices and beliefs also vary widely, as does the organization of care giving and disciplining.

In this article we draw upon data from several cultural and transnational contexts to explore how beliefs about children and childhoods enter into and influence processes of migration. We examine children's physical movements across national borders, and how the presence and actions of children may help families stay connected across those borders. In the larger project we focus centrally on children's perspectives, but we concentrate here on adults' decisions, because adults have considerable say over how and when their children migrate and/or return.

\section{“California Childhoods": Methods of Inquiry}

Our focus on transnational social practices is one strand of a larger ethnographic study of childhoods in two urban areas of California that differ in social class and ethnic composition and in histories of immigration. This collaborative research project involves researchers from a range of national, ethnic, social class, and language backgrounds, and of diverse ages; we work to bridge the complex worlds that come together, at least physically, in these urban 
areas. We came to focus on transnational issues through the inductive processes of qualitative research, and we generated insights by using multiple sources of data. The theme percolated over several years, during which we continued the iterative process of data gathering, analyses, reading, and consultation with colleagues.

When we first embarked on this study, we assumed that the project would examine social processes that take shape within delimited communities or neighborhoods. We chose areas with high concentrations of immigrants because we wanted to explore the effects of rapid demographic changes on children's lives, as well as variations in cultural practices. We began the work in 1995 in the Pico Union area of Los Angeles, a "first stop" immigrant area for migrants from Mexico and Central America; a small number of Korean immigrants also reside in this area, which borders on "Koreatown." The following year, we began gathering data in our second site, an ethnically diverse, mixed-income area of Oakland.

In each community, we mapped the contexts of children's daily lives, across lines of social class and ethnicity, and traced the construction of varied childhood experiences. Through this mapping, we came to see that the organization and meanings of immigrant childhoods often extend across national borders, and fieldwork insights led us to our exploration of transnational childhoods. For example, in our Los Angeles field site we asked children in an afterschool program to draw maps of places where they spend time. Eleven-year-old Guayo drew his "casa" and nearby Los Angeles sites, Guatemala (where he was born and where "nearly all" of his relatives live), and four other places in the U.S. where his extended family has moved seeking jobs. In the same field site, more than half of the students in a first grade classroom where we regularly observed told us that they have siblings living in their home country. Most of these children had made at least one trip to visit family members back home; a few visited every year.

In Oakland, our other field site, the teacher of a third-grade "sheltered English" class asked students to draw themselves as a growing tree, with "roots" reaching to things that give their lives meaning. Several students drew roots to people and places quite far from Oakland. For example, Arwa, a nine-year-old girl who was born in Oakland and whose parents came from Yemen, drew herself connected to a row of neighborhood places. At the end of that urban landscape she sketched an apartment building labeled "Yemen." In a classroom essay, Arwa wrote: "Yemen is kind of fun, but when you get on a plane it's really scary."

The Pico Union community is the central focus for our analysis of transnational practices, because most of the residents have recently migrated from their home countries and are actively considering the option of returning; thus transnational circuits are continuously being reconstructed and negotiated. To foreground this case, we draw on more than three years of fieldwork by Marjorie Orellana and two research assistants, as well as Orellana's ten prior years of involvement in the Pico Union community as a teacher and an activist. Fieldwork included participation in classrooms and on the playground of a large elementary school, in homes, after-school programs, the public library, and other child-related sites. Orellana facilitated three focus groups with parents in order to explore families' histories and experiences of migration, and parents' views of their children's daily lives. (These were conducted entirely in Spanish; they were videotaped and transcribed.) In one of the focus groups, all of the participants had children both here and in their countries of origin. The research team also conducted fourteen focus groups with fifth grade students, inquiring into kids' daily lives, including transnational experiences. In order to more fully grasp children's perspectives we invited kids in three classrooms and two after-school programs to draw and write about their lives, and we gave some of them disposable cameras to take pictures in California, as well as on trips to their home countries (Orellana 1999). All of these data illuminate our analyses of children's participation in family migration projects.

In the course of this fieldwork with Central American and Mexican families, we came to see the value of adding a comparative dimension to the study of childhoods in this geographical area. Anna Chee joined our team and began observing in the classrooms of Korean stu- 
dents (in 1999, these students represented less than $2 \%$ of the school population, down from $10 \%$ in 1990) and in after-school and tutoring programs that serve this immigrant population. After we identified transnational practices as a key area of interest, Chee pursued an opportunity to gather data and learn from Korean "parachute kids" — children who live or board in homes in the U.S. (in this case, in a Los Angeles suburb) while their parents stay in Korea. She conducted in-depth interviews with four of these children, a mother, a father, caretakers, and other relatives in 1997 and again in 1999. We include this case because its dramatic nature helps to challenge traditional frameworks for thinking about children; it is a useful case for exploring children's participation in immigration processes.

One of the immigrant groups in the Oakland area is an extended family network from Yemen. Barrie Thorne got to know these families, interviewing two mothers, one of them several times, and three children of different ages. She and other fieldworkers also observed and had many casual conversations with the Yemeni children in settings in and outside of school. We use this as our third contrasting case because transnational connections between Yemen and the Bay Area are unusually well established, and the social class dimensions of the Yemen and Korean cases offer important points of comparison with low-income immigrants in Pico Union.

\section{Children and Transnational Social Practices: Three Empirical Cases}

Transnational social fields are grounded in real social relations, not in an abstract metaphysical space (Guarnizo and Smith 1998), and they vary in history, organization, and patterns of use. We begin with a brief description of each case and a summary of their comparative dimensions. Following this, we turn to more analytical terrain, examining children as a distinctive and internally diversified category of social actors. We explore the varied ways in which children figure within the horizons of need and opportunity in migration processes, and in the constitution and uses of varied transnational social fields.

\section{Migrants in Los Angeles with Close Ties to Mexico and Central America}

Central American and Mexican immigrants in the Pico Union area of Los Angeles come from diverse backgrounds in terms of educational experiences, hometown origins, and cultural identification. Once in Pico Union, most of the adults go through a racialized process of proletarianization (Rouse 1992), finding employment in low-wage jobs in the garment industry and in restaurants, or as day laborers, janitors, gardeners or paid domestic workers. Others, especially women, create their own employment niches in the independent sector by selling food and other items within the community (Chinchilla and Hamilton 1992). These migrants have come to the U.S. to escape political and economic instability in their home countries and to earn money, some of which they send to relatives back home. Many of the immigrants who live in Pico Union are undocumented, or are in the process of securing documentation, a legal status that places them at risk and limits their options. Both men and women have high rates of employment, although much is in the informal sector, with high rates of job instability. Virtually all of the children in schools in Pico Union qualify for free or reduced-price lunch according to federal income guidelines.

Families who have recently immigrated to Pico Union sustain close ties with primary and extended family members still living in Central America or Mexico, and there is considerable movement and communication back and forth. Economic and political contingencies, citizenship status, patterns of dependence and responsibilities for care giving all enter into families' varied configurations of movement between Pico Union and places of origin. Migrants are often lured by stories told by their family members about both immediate resources-employment, with wages paid in dollars-and long term possibilities for education and economic advancement, in contrast with the lack of possibilities, and dangers seen back home. Condi- 
tions in the U.S. generally turn out to be much more difficult than anticipated, however, and multiple families often share small apartments in the Pico Union area in order to manage the high cost of living in Los Angeles.

\section{"Parachute Kids" Who Migrated from Korea to Attend School in the U.S.}

During the early 1990s, Asian families with economic means (in part because of a boom in their home countries' economies) began to send children to the U.S. to attend school with the hope of eventually gaining admission to U.S. colleges or universities. The migration of "parachute kids," as they are called in the media, is also part of a long-term transnational strategy for economic advancement. These families hope to use the knowledge and networks their children acquire abroad as entree into the country and as part of an entrepreneurial strategy for widening their economic fields of operation (Ong 1999). In the case of South Korean "parachute kids," this strategy also allows parents and children to avoid the intensified competition for slots in top Korean universities (Cho 1996). By enrolling children and adolescents in U.S. schools with the hope of eventually getting U.S. college degrees, parents and children can channel aspirations into an alternative mobility track.

In 1997, a former employee of the Korean Ministry of Education estimated that 7,000 "early international students" (a name used by some officials for this group) were enrolled in elementary and secondary schools in Southern California. The students enter the U.S. on student visas or on visitor visas that they later try to change to student visas. In the highest profile cases, written about in the popular press, "parachute children" may receive considerable amounts of spending money from their families, as well as homes to live in and maids to supervise (Hamilton 1993; Zhou 1997b). In most cases, however, including the situations of the four Korean "parachute kids" in our study, the children live with relatives or board with Korean American families living in suburbs reputed to have good public schools. Parentsusually the mothers-may help to monitor their U.S.-based children by visiting regularly or dividing time between the two countries. Shifting out of the tightly tracked South Korean educational system makes it difficult to return, however and, as we will describe, after the Korean economy collapsed in 1997, the families of the four children we followed were in a state of crisis.

\section{Yemeni Families Who Live in Oakland and Sustain Active Ties "Back Home"}

Migration from Yemen to the U.S. began in the 1960s when impoverished conditions led as many as a fourth of adult men to seek employment in other Middle Eastern countries, and eventually in places further away (Swanson 1988). Following a sojourning pattern that involved sending regular remittances to their families back in Yemen, the men who sought work in the U.S. clustered in two niches: industrial jobs in Detroit and migrant farm work in the west. After 1975, when prices rose in Yemen and it became more difficult to acquire land and property there, more of the itinerant workers settled in the U.S. and other family members joined them. Some went into business, mostly through the labor-intensive work of running small grocery stores or newsstands.

The grandfather of one of the two extended Yemeni families living in our Oakland field site followed this pattern. Mr. Assad came to California in the 1960s to pick grapes as a migrant worker. He saved money and purchased a small grocery store near Fresno; later he moved to the East Bay and purchased small business properties. He sent remittances to his wife and child in Yemen, and eventually bought property there as well. His wife and son moved to Oakland in the early 1970s and three more sons were born here. In contrast with the migrants in our study who came from Mexico and Central America, Yemeni women have not been active participants in the labor force (although some do hold jobs) and, according to Mrs. Assad, women never take the lead in migration. 
In 1997, when we got to know them, Mrs. Assad, the sons, their wives (two of them sisters from Yemen; the other two, also sisters from another Yemeni family in the Bay Area), and the children lived in four units of a family-owned apartment building. The senior Mr. Assad was then living in Yemen, where he had a second wife and young children. Over the next two years, he twice returned to Oakland with the children for several months. The children attended elementary school with their half-aunts and uncles and then returned to Yemen. The Assad family maneuvers in a well-established transnational social field, knitted through patterns of dual citizenship, property ownership, ongoing economic activities, and thick kinship ties. As we will later detail, family practices also connect their daily life in Oakland with relationships and activities in Yemen.

Comparative Dimensions. These three cases highlight variation in the structure and dynamics of transnational social fields. By selecting cases that vary on important dimensions, we aim to illuminate the multiple ways in which children enter into family migration processes. We use the cross-case comparisons to generate insights that would be less evident through a study of a single group. (We note, however, that each orbit of back-and-forth migration is also internally differentiated, including individuals and families from varying class backgrounds and with differing degrees and types of attachment to places of origin.) Before moving to an analysis of children's presence in each of these transnational circuits, we summarize key differentiating dimensions across the three cases:

1) The groups are in different historical stages of immigration (the Yemeni network in Oakland includes second and third generation immigrants, while most of the Central American and Mexican immigrants to central Los Angeles are the first members of their families to venture north, and the Korean "parachute children" are potentially opening up pathways for their own parents).

2) The populations vary in density, which affects their visibility in the urban landscapes of Oakland or Los Angeles, as well as the tightness of their networks.

3) Social class and access to legal entry figure centrally in patterns of movement and differentiate the experiences of these three groups. Most Mexican and Central American families in Pico Union have few economic resources for maneuvering in transnational space, including the means to secure visas for initial entry, while the more affluent Korean families we studied have latitude to create long-term strategies. Although first generation Yemeni immigrants were impoverished, several decades later the families we studied had purchased property in both countries and attained high rates of citizenship; these resources facilitate movement back and forth.

4) Access to institutional networks and resources affect the ease with which people move across national borders. Many Korean "parachute children" establish contact in the U.S. through Korean churches; some Central American political refugees have also had their pathways facilitated through connections with U.S. churches and other international organizations. But most of the Central American, Mexican, and Yemeni families we met had no such access to powerful institutions.

5) Cultural practices weigh in, most visibly in the Yemen case; some of the first generation male immigrants practice polygamy, sustaining parallel and interconnected households in Oakland and in Yemen. The practice of arranging marriages back in Yemen helped sustain transnational family ties into the second and third generations.

6) Vicissitudes of the global economy rippled through the fortunes of each of these groups, most dramatically (as we will describe) in the case of the Korean "parachute kids."

7) Political changes, such as the passage of proposition 187 in the U.S. and patterns of war and peace in Guatemala, El Salvador, and southern Mexico also affect patterns of movement.

8) Finally, geographical distance influences the possibilities, ease, and cost of travel, but may, at this point in history, be of lesser importance than other considerations in shaping transnational practices. 


\section{Bringing Children into Analytic Focus}

The structural dimensions of these varied social fields help situate the specific transnational childhoods that we will now bring into fuller view. They also highlight varied conceptions of the needs and capacities of children of different ages and genders. Children are defined and positioned by laws (e.g., regarding citizenship, child labor, parental obligation, requirements about school attendance, and eligibility for government programs) that vary from one country to another. Children are also positioned, with much variation by age and by cultural framing, as legal, economic, and emotional dependents in need of adult care, labor, and economic provisioning. As they grow older, children become more capable of caring for themselves and contributing to the labor that sustains the daily life of families (e.g., caring for younger siblings, the sick, the elderly; doing housework; engaging in paid work). But this move to self-sufficiency and capacities for labor is perceived and organized in a range of ways, which may be contested. Finally, children are positioned as a special category of people whom parents and other adults actively seek to "raise" and "develop" toward desired endpoints.

A moving dialectic of child and adult agency is bound up in processes of "growing up" and of "raising" a child-paired terms that allude to a mix of daily, cyclical time and the sweep of cumulative time entailed in the passage from childhood to adulthood. Growing up/bringing up is a guided but open-ended and highly contingent process, involving conflicts of will and struggles over autonomy and control (Thorne 2001). Children ages five to seventeen, who are the focus of our research, maneuver in an in-between zone, still dependent and in need of adult protection and active care (although to varying and contested degrees), but also increasingly capable of independent action. Children's negotiation of autonomy may take particular twists when adult-child relations are situated within transnational social fields. All of these facets of child/adult relations - the legal positioning of children and of parents; patterns of economic dependence and divisions of labor by age and gender; beliefs and practices entailed in bringing up children and (from the child's perspective) growing up-enter into the complex dynamics of family migration.

\section{Children and Patterns of Migration}

How does the presence of children enter into decisions by individuals and families to migrate, stay, "settle," or return? Much of the literature on patterns of migration is framed by an emphasis on material realities-households, resources, divisions of labor, the use of migration as a way of escaping economic hardship and seeking new opportunities (e.g., Arzipe 1982; Harbinson 1981). This literature treats children, in effect, as luggage, as in phrases like "the immigrant sent for his wife and children." Feminist scholars helped women move to active conceptual presence in studies of migration (e.g., Hirsch 1999; Hondagneu-Sotelo 1994, 1999; Pedraza 1991; Tienda and Booth 1991). But children continue to be portrayed as burdens weighing down otherwise mobile adults. This image, of course, contains a good deal of truth, especially with respect to the demands posed by the care of small children. Bringing up children requires adult labor, although just what kind is believed to be needed, or actually provided, varies by culture, social class, and place. Marxist and socialist-feminist theories of reproductive labor highlight the range of tasks involved in caring for and raising children, as understood from adult perspectives (Laslett and Brenner 1989). More recent conceptualizations of "caring work" (e.g., Ruddick 1998) add relational nuance and emotions to the study of reproductive labor, as do notions like "the work of developing the child" (Walkerdine 1984). To bring children more fully into knowledge, it is important to examine not only the organization of reproductive labor and relations of care, but also children's participation in social processes (James and Prout 1997; Thorne 1993) and the ways in which they grow up 
and change over time. Children contribute to family divisions of labor and relations of care, and they express their own wishes with regard to moving or staying.

\section{Chain Migration, in which Children May Be "Left Behind"}

"Stage" or "chain" migration is a common pattern for Mexican and Central American families in central Los Angeles, and for the Yemeni families in Oakland. One or more adults migrate first and gradually send for, or receive, other family members. There are differences, however, in the two chain patterns. In Mexican and Central American families, children are often the last link in the chain, following their parents who migrate either together or separately. Among the Yemenis we studied, adult men migrated first, sometimes followed by their oldest sons, with mothers, daughters, and younger children of both genders coming together at a later point. The Yemeni families we talked with said they knew of no children who stayed behind after the mother migrated. In both cases, the spacing of links in the chain depends largely on financial resources, but resources vary dramatically. It may take years for the lowincome families in Pico Union to reunite their families; the process was much more consolidated for the more affluent Assad family in Oakland.

Central American and Mexican families with young children often make arrangements for children to stay with relatives in the home country. They do this in order to avoid the uncertainties of life during the transition, and to protect children from the dangers they could encounter en route, traveling by land and crossing the U.S. border without legal documents. (Yemeni families, on the other hand, have little choice but to secure airline tickets and visas in order to enter the U.S., and so those who do so have the means to secure visas and pay for tickets.) Whether or when children are "sent for" depends on different factors: money to pay for the journey; the needs and circumstances of family members here and at home; the expressed desires of the children themselves; and parents' views of what is safe, appropriate, possible, or good for children of different ages and genders.

Alma Martínez, the mother of a seven-year-old boy living in Guatemala, and a six-yearold girl living in Los Angeles, carefully weighed her wish to be reunited with her son against her sense of what was best for him. In a focus group, she explained that she didn't want to bring her son here because he was accustomed to freedom of movement in the countryside at home. If he came to Los Angeles, it would be "to be shut up inside with me, nothing more. He might get sick, or not be able to stand being here." ${ }^{1}$ She compared the situations of her two children:

He enjoys a little of what she doesn't have here. And she has a little more of what he can't have over there. The ones that are over there don't have material things, but they have freedom. My son has his grandparents, his cousins, his uncles and aunts and all. And my daughter here is alone, closed up in an apartment filled with toys. Even if she has a closet overflowing with toys, she's stuck inside. $^{2}$

1. All quotes are from the original Spanish (translated into English by Orellana) or Korean (translated into English by Chee); all of our Yemeni American informants speak English.

2. It was not easy to tap children's perspectives on the differences between life in the U.S. and in their home countries, though we asked in a variety of ways and in different contexts. Children whose parents are not legal residents may protect their families by not talking about their transnational ties. And when they are immersed in their daily lives in Los Angeles or Oakland, "over there" may seem very far away, not easily formulated into words to respond to the prying questions of researchers. When we asked, kids talked about seemingly mundane differences between here and there ("the paper there it's more crinkly"); some of these everyday observations seemed to tap into their understanding of economic and/or urban/rural divisions as, for example, when 11 year-old Muhammed noted about Oakland, in contrast to Yemen, "there's hardly rocks around here. It has a freeway. That's it." Kids also mentioned differences in forms of play ("in Yemen I never used to like it because there was too much kids that throw rocks and have a lot of fights"). When we asked children what they liked about their countries of origin, the responses seemed to tap into the same aura 
Sra. Martínez and the other mothers who talked together in a focus group in Los Angeles held on to the hope that their children had more opportunities here than did children who remained back home, though they may pay for their futures with the loss of childhood freedom. Wilma Díaz, on the other hand, said her fifteen year-old daughter wanted to join her here, and she wanted to bring her from El Salvador, because a girl that age has to "watch herself"- or be watched-and she worried that she was not there to do the watching. But the girl's age and gender might also make her more vulnerable to dangers in the journey north. Sra. Díaz knew what was involved and did not want her daughter to suffer in making the trip.

When possible, Central American and Mexican parents arrange for young children to make the journey in the company of other kin. Sometimes, however, no one is available to accompany the child. Nelson Ornelas told of how his nephews were captured by border patrols and sent back to Guatemala. They were six and eight years old at the time, and had been traveling with a group of adults, none of whom were directly responsible for them. Sra. Martínez told of a five-year-old boy she knew who recently came from El Salvador by plane. It took five days for "coyotes" to pass this boy through Texas and into Los Angeles (for a fee of $\$ 3,000)$, but the dangers of crossing by land were avoided. Questions about how and when to send for children sparked animated discussion among participants in the focus groups. The decisions these families make contrast sharply with those of middle class, non-immigrant families in Oakland who worry about the right age to allow their children to walk a few blocks alone to their friends' homes to play.

In their talk about bringing children here (or in the Central American and Mexican case, sometimes leaving them behind), parents frame children both as in need of adult labor and care and as "persons being developed." They are concerned about children's health, wellbeing, and futures, and they make decisions about what is best in relation to both short-term opportunities and long-term hopes and dreams. Parents navigate, of course, within the constraints of available resources-resources that vary dramatically across the two cases. Parents who "left children behind" worried about them-that they would not be well fed, clothed, or cared for; that they would feel abandoned or unloved; or that something terrible would happen to them while out of parental reach. But by working here and sending money home, parents could provide for their children and offer possibilities for their futures. Elsa Fuentes explained: "It's just something we have to do now. Even if we don't want to. Nobody wants to leave their kids." Sra. Martínez talked frankly about the terrible costs:

Look, something happens. Beyond the fact that they stop loving you, and all, let me also tell you that what also happens is that you lose your love for them. Because, look, I tell you that I love this girl (her daughter in Los Angeles) a lot, and I won't be separated from her. Because the other one, I did leave. And with time, you start losing your children's love, and also losing your love as a mother.

"Leaving children behind" frames children as dependents. Their care depends on the willingness of kin to provide for them and on the financial support that families are able to send back. Because Central American and Mexican families generally operate with a notion of family that includes extended relatives, "other mothers' children" (Dill 1994) may not be seen as

of freedom that parents noted; kids talked about life in the countryside, and about chickens, cows and other animals. Their comments include: "it's beautiful”; "it's all sparkly"; "it's like cool." Of course, children's geographically-associated feelings of freedom may be bound up with freedom from the temporal and institutional constraints of their daily lives in Los Angeles; they also talked about going to water parks and other excursions with their families while on vacations in their home countries. When we asked 11 year-old Adalia, who visits Guatemala each year with her family, what she likes best, her response sounds like one that could apply to family vacations in the U.S.: "The parks, the, like, you know, here it's Disneyland and Six Flags. There, it's water parks with a lot of slides, and it's cool." Similarly, 12 year-old Ahmed compared amusement parks in Oakland and in Yemen: "I like this place because they have games. They have roller coasters. . . I I like roller coasters. I like here. But the crashing cars and stuff, and the circus, I like that there, in Yemen. Because they have more better ones there." 
a burden. Children contribute to the households in which they live (here or there), helping with cooking, cleaning, and the care of younger children and often with labor outside the home (for example, in household street-vending projects). These children are simultaneously deployed in family labor systems and positioned as dependents requiring care. They may represent a boon to their households when their parents send money to their caregivers. However, the extended family may also feel pressed financially, and come to see extra children as a burden. Sr. Ornelas described his own youth in Guatemala, between the ages of 8 and 15, after his mother went to Los Angeles to seek work in the garment industry, and he was "passed around" from one older sibling or aunt to another. He contributed to each household in different ways (cutting and selling firewood; helping local fishermen in exchange for a few fish), but he felt like he was an extra mouth to feed. [See Olwig (1999) for similar insights into the perspectives of children who were "left behind" in the Caribbean when their parents migrated abroad.] Sra. Martínez told of the strains inherent in the economic and emotional transnational interdependence she had with her mother-in-law:

Sometimes, like right now it has been four months since we've sent a penny to my mother-in-law. And it's a little difficult. Because my mother-in-law gets really mad. She tells me, "You left me with a grandson, not a son." She says, "Remember to at least send the money."

When families in Pico Union send regular remittances back home to provide for their children or other relatives-one of the most important sources of "foreign aid" for their home nations and of sustenance for individual families (de la Garza, Orozco, and Baraona 1998; Mahler 1998) - they have fewer resources to invest in "getting ahead" in the U.S. The welfare of children born here may be pitted against the welfare of those back home. To buy nonessential items—such as books, toys, meals at McDonalds, or other things their children ask for-means less money to send back. Parents expressed frustration that their children here didn't appreciate the things their children back home would never have, and they thought about "sending kids back" to give them another perspective on life.

\section{Children Taking the Lead in Migration}

During times of war, children have sometimes left their countries unaccompanied by adults (Ressler, Boothby, and Steinbock 1988). Rumbaut (1994) describes the "Peter Pan" phenomena in which 15,000 Cuban children arrived in the United States between the years of 1959 and 1962. In Los Angeles and Oakland, there are children of war from Vietnam, Cambodia, El Salvador, Guatemala, Nicaragua, and southern Mexico. These situations challenge a view of children solely as dependents, and force recognition of the ways in which geopolitical forces shape the contexts in which children grow up. ${ }^{3}$

The migration of "parachute kids" from South Korea also challenges mainstream U.S. notions of what children can and should do on their own at particular ages. These children have taken the lead in a process that may eventually result in the chain migration of other family members. Parents made the arrangements for their children to live and study in the U.S., and the children continue to depend on their families' abilities to pay the costs of their stay. The migration is framed by the goal of "developing" the children toward an adult destination valued by their families: college graduation and a professional career. From another vantage point, "parachute" children serve as deployable resources for their families' future positioning in a reordered global economic sphere. Children labor as students, not for their immediate household sustenance, but to advance their families' social and economic mobility.

Some Korean "parachute children" live in boarding homes rather than on their own. When first interviewed, Tae and Daniel Hoon were boarders with Mr. and Mrs. Park in subur-

3. Whether or not immigrants are recognized as refugees depends on U.S. policies. Most of the Central American children in Pico Union are here as a direct or indirect consequence of civil wars, but there is little official recognition of the traumas they may have experienced. 
ban Los Angeles. Tae was seventeen and attending a public high school; he migrated to southern California when he was fourteen years old. Daniel, who was in seventh grade in a public middle school, migrated when he was ten years old and in the fourth grade. The Parks, who came to the U.S. from South Korea in the early 1970s, took in boarders (arrangements made through the Korean church they attended) to boost the family income; they received \$1,000 a month for each child. In an interview, however, Mrs. Park framed her talk about the children from the perspective of a surrogate parent, expressing concern for their health, educational progress, and emotional lives:

We have to be parents for Daniel and Tae. We make "Kim Bob" (Korean sushi) and take them to the park. I used to wake up two, three times a night to check if Daniel is covered up. Daniel used to ask me to turn off the light in his bedroom every night. . . I have to provide good home-cooked meals every day. Mr. Park has to give them rides each time. We are doing our utmost, but we won't be able to relax until they get into a college or move back to Korea.

Other "early international students" live with relatives in the U.S. Cindy and Bill, cousins who were each seventeen years old when first interviewed, came to the U.S. from South Korea in 1990 when they were nine and moved in with their paternal aunt, cousins, and grandmother, who migrated earlier to a suburb of Los Angeles. The Choys did not receive money for providing a home for Cindy and Bill, an imbalance of reciprocity that affected the children's relationship with their aunt. The aunt, Mrs. Choy, observed that Cindy "does not say anything around the house. She has always done what I asked her to do. She never says, 'I don't want to or I can't.' I believe this is due to the fact that she is not living with her own family." Cindy said that she rarely goes out of the room she shares with her grandmother: "I always stay in here."

Asked how the parents back in Korea felt about this arrangement, Mrs. Choy replied that her mother calls her sons (fathers of the "parachuting" cousins) a few times a month. "Cindy's mother always says, 'I'm sorry, I have no words.' When she talks to Cindy, she asks about her school grades and says, 'listen to your grandmother and your aunt, help them.' " Mrs. Choy said that her younger brother (Bill's dad) avoids her altogether. In a way, these migrant children left one type of labor — the demands of competitive schools at home (Cho 1996)—for other types of labor. This new work involves doing well enough in U.S. schools to justify their parents' financial sacrifice; and helping out with household labor, and restraining the expression of their emotions, in order to lessen the burden their presence posed to other relatives. [Ong (1999) notes that young Hong Kong immigrants, similarly sent to the United States to establish a base for their families, also do the work of establishing "symbolic capital" for their families by accumulating and displaying credentials, goods, and social trappings, including those marked in their own bodies, for example by working out and dressing in particular ways.]

Shifting economic trends pose another type of risk. After the 1997 economic crisis in South Korea, some parents could no longer send money to their children in the U.S., leaving kids feeling stranded between the two countries. According to an article in the Korea Central Daily (Kim, Bae, and Oh 1998), the Korean Ministry of Education estimated that of the 35,000 elementary and secondary school age children who had left Korea since 1977, about half would return by the middle of 1998 due to the economic crisis.

The four "parachute kids" in our study expressed anguish when they were re-interviewed in 1999. Daniel's parents declared bankruptcy at the end of 1997 and had to drastically reduce the amount of money they could provide him and his two older sisters, who were "parachuting" in the U.S. in another location. At one point, U.S. immigration agents found out that the children were attending public schools on F-1 student visas. The oldest sister was allowed to finish her last semester of high school, and the mother found a private school, with a hefty tuition, that was willing to enroll Daniel and the other sister in the middle of the year. Daniel wanted to stay in the U.S. where he experienced more freedom (a somewhat different con- 
struction of freedom than discussed by Pico Union families) and where he had a better chance of getting into a good college, but did not know if his father would be able to pay the tuition. Daniel had heard of other "parachute kids" who returned to Korea and found themselves in trouble in school both academically and socially, and he anticipated that "they will say that I have an accent, that I cannot speak Korean properly; they will beat me up just for those reasons." At the same time, Daniel noted that immigrant kids and parents looked down on "parachute children": "Because we live without our parents' supervision, they think we are doing something bad. They do not want their children to play with us." Daniel's position of feeling caught between two nations, educational systems, and ways of growing up, conveys one of the risks of transnational childhoods-feeling marginal in both places.

\section{"Sending Kids Back"}

Migration patterns have never been uni-directional. In the early twentieth century, there was more back-and-forth movement by immigrants from Europe than is generally realized, although mostly by single men (Daniels 1990). Rouse (1992) notes that Mexican migration, especially before the 1960s, was mostly temporary and circular. Stack and Cromartie (1992) discuss the back-and-forth movement of African American children between kin living in the north and in the south of the U.S. Basch, Schiller, and Blanc (1994) describe children moving between the U.S. and their home country as part of their families' processes of "building transnational social fields," and Soto's (1987) studies of "child fostering" include cases of children who returned to the Caribbean after spending time in the States. This circular movement is sometimes set in motion by the deployment of children to help relatives in the home country. It may also be a strategy for reshaping a developmental trajectory that, in the view of adults, is going "off track" (Matthei and Smith 1998; Menjivar 1999). Whatever the specific reason, the movement of children between countries helps maintain "historical and cultural continuity between the migrants and the communities that send them forth" (Soto 1987:131). Without the presence and active participation of children, some transnational networks would not be sustained.

In our fieldwork in both Pico Union and Oakland, we found that Central American, Mexican, and Yemeni parents keep open the possibility of "sending their children back home" in order to avoid problems, especially when children reach adolescence. In a focus group discussion, Ivan Macías, who immigrated to Los Angeles from an indigenous community in southern Mexico with his two sons (in high school at the time of the discussion) and a daughter (in third grade), explained:

On television we see that so many things happen in the schools, and that the kids are forced to join gangs or take drugs, and so sometimes it makes us a little fearful about that and we want to go back to Mexico, so they can study there, from secondary school on.

The threat of being "sent back" is sometimes held over children who show signs of getting into trouble. Jorge Sánchez, the father of a second grade girl in Pico Union and of four older children in Mexico, said he was considering sending his daughter to Mexico because her teachers complained about her behavior at school. He also felt that Anita didn't appreciate all that she had here, compared with the hardships of life in Mexico. Anita understood that she was going back to Mexico if she wasn't "good." Whether or not a threat is carried through is influenced by the gravity of the problem, the resources available for sending children back, the willingness of family back home to receive them, and of family here to let them go. Children's protestations also may weigh in. Our fieldwork in Pico Union suggests that relatively few of these threats are acted upon; but the possibility of invoking "transnational disciplining" serves as an important strategy for parents to control children's behavior.

The Yemeni families in our study have more economic and political stability, and their well developed transnational social sphere makes this form of disciplining a more practiced option than it is for migrants from Central America and Mexico, in part because children can 
be more readily retrieved after they have been "straightened out." Afrah Assad explained that, "It's back-and-forth all the time now; you buy a ticket and visit the other family, then come back. It's no different than going on a trip to the shopping mall." She noted that when their children were small, she and her husband took them back to live and attend school in Yemen for a year and a half. Since everyone there is poor, the children came to "appreciate it here" in the U.S. She sees the teen years as an especially risky time, when children sometimes drift from Yemeni and Islamic traditions. If a daughter goes astray, especially if she shows interest in boys, she may be hastened into an arranged marriage with someone from Yemen or the Bay area Yemeni community, or pulled out of school to do home study. If a boy gets involved with girlfriends, alcohol, drugs, or "abusing the family," the family may send him back to Yemen; according to Mrs. Assad, home schooling was not an option for boys because "if you tell them to do it, they won't finish it. They have to be in school."

Mrs. Assad's sister and her husband pulled their fourteen-year-old son out of an Oakland middle school because he was "hyper and out of control and wanted to smoke." They sent him back to Yemen, where he was getting "straightened out" by his grandfather, in part by working for him (he was not legally required to attend school in Yemen). Mrs. Assad described a pattern: "They go home, we let them stay a year or more, they come back different people. They have less there; people are hungry and poor. They change their minds and decide they're going to be good." In another conversation, she elaborated, "When they went back home they got in touch with what we're talking about. It's like you tell a story about back home, but they don't know the place. But if they go there, then they appreciate it." Mrs. Assad did not want to deny her children material goods or other opportunities, but she wanted them to appreciate their privileges and to remain loyal to the family and its religious and cultural traditions. Using "back there" as a reference point helped her frame this childrearing strategy. This seems not unlike the historical reference point used by non-immigrant parents ("when I was young, we had to . .."); but it may be more effective because children can actually experience the differences that adults name. Geographical distances can be crossed in ways that temporal ones cannot.

The child-rearing strategies described by Mrs. Assad and her children mix the schooling and labor of children-boys helping out in the liquor store in Oakland or working on the farm back in Yemen; girls starting to do housework and childcare at young ages-with a discourse of "developing the child" guided by Islamic and Yemeni traditions. A firmly established transnational social sphere facilitated these parenting goals, and Mrs. Assad was determined that these ties would continue in the next generation: "We have a saying, 'your country is your first mother. You can't stay away from your mother, your country, or your family back home.' " It also helped families to keep their own priorities clear-as Mrs. Assad said, "We go back and forth to keep life straight;" and, presumably, to keep it straight for their children.

Ironically, some adolescents are "sent back" when they fall into trouble, but not by their families, and not for the purpose of correcting their developmental pathways. When teen gang members are arrested for criminal activities, they are easily deported back to their home countries. Wallace (2000) notes official estimates of 20,000 full-fledged gang members in San Salvador, many of whom got their start in gang activity as immigrants to Los Angeles. These gangs can be understood as youth-established transnational social fields (Matthei and Smith 1998).

Falling into trouble is not the only reason children of migrants may return, or be sent back to their parents' countries of origin. Some Mexican and Central American families told us that they were contemplating sending their children back home for schooling or other opportunities. All of these parents say they came to the U.S. to seek educational opportunities for their children. But changes in the political climate threaten the futures they sought for their children. These parents are actively considering the option of returning, or sending their children back while they remain here to work. Ronaldo Padillas, a college-educated Salvadoran who left his war-torn country in the 1980s commented: 
It is so worrisome that they want to take school away from people who aren't residents here, under Proposition 187. So you have to look at options... Y You think that if it looks really hard for kids to get an education here-because we struggle not for us, but for our children-then, what can you do? You have to go to where you can keep on studying.

However, children who have been schooled in Los Angeles, where the school district seeks to move children into all-English instruction as quickly as possible, may have great difficulty returning to study in their home countries. (Before 1998, most teachers working in bilingual programs aimed to move children into "all English" by third or fourth grade. In 1998, a popular initiative was voted into law in California that severely restricted the length of time in which children receive native language support; many children now spend less than a year learning to read and write in their native language.) The loss of their home language, or its lack of development for academic tasks (Wong-Fillmore, 1991), may be an important factor that keeps children here, while children who are more fully bilingual have more transnational options.

Changes in U.S. social policies, such as the Welfare Reform Act of 1996, also enter into decisions to send children back to the home country. In 1998, Elsa Morales, a Pico Union mother who received AFDC for her three U.S.-born children, said that she was planning to send the children back to Mexico to be cared for by their aunt. The only employment Sra. Morales could find was as a live-in domestic worker, and her children couldn't live there with her. "Reverse migration" patterns, in which children with U.S. citizenship are being sent back to be schooled in Mexico, counter the image of undocumented immigrants "taking advantage" of U.S. schools. U.S. immigration and social service policies, such as Proposition 187 in California, create a climate that may transfer more of the costs of reproductive labor abroad, effectively increasing the exploitation of wage workers here (Hondagneu-Sotelo 1995).

\section{Staying Connected}

When family members are physically separated for long periods of time, they have to work to stay connected. (Alternatively, they may lose touch and establish separate lives.) Families may have no physical contact for a decade or more while those in the U.S. work toward securing papers for their reunification. As Dill $(1988,1994)$ notes, families of color in the U.S. have, historically, had to struggle to "do family" in the face of divisive forces like slavery, immigration policies, or economic and political conditions. Families who do this relational work across national borders actively build transnational social fields.

Members of families who are separated by large distances stay in touch through various means of communication. This includes the traditional form: handwritten letters (see Sienus [1992] for a collection of letters written between Mexican and Central Americans and their families back home; see Guerra [1998] for a discussion of transnational literacy practices in a Mexican community in Chicago). Letters are sometimes sent through regular mail, but increasingly, Central American and Mexican families use special delivery services established by other immigrants. Since families feel compelled to send money with letters, communication may falter if there is no money to spare. Immigrants feel that folks back home won't understand if they tell them they don't have money to send. As a parent who participated in a family literacy project in Pico Union wrote: "People over there still think that people come here to make money. If you go and tell them that's not so, they say that you're selfish" (¡Aquí Vivimos! Book Project 1993:43). The immigration process shifts real or perceived relationships of power and reciprocity among family members, and the shift may strain family relations.

Families also communicate by telephone, despite the cost of international calls. After they first came to the U.S., the "parachute kids," Cindy and Bill, spoke with their parents by phone fairly regularly, but less often as time passed. The cost of the calls was a factor, but Cindy and Bob also noted that it was difficult to communicate as daily life here and back in Korea increasingly diverged. Bill said that when his mother phoned: “. . we don' $t$ talk. She gives the 
phone to my brother. He doesn't say anything. I don't say anything. I don't think we have nothing to say." Zhou (1997) describes "parachute kids" from Taiwan who also experienced estrangement from parents.

Families who are economically pressed have difficult decisions to make: communicating by phone allows for much more personal, real-time contact than do other means of communication, but paying for these calls means there is less money to send back home. Sra. Díaz said that she calls her daughter once a month, but sometimes the bill runs to $\$ 40$ or $\$ 60$. Sra. Martínez noted that she has to monitor her daughter's use of the telephone at home. This six year-old had memorized her brother's phone number in Guatemala, and "if I'm not careful, she calls and calls."

Modern technology allows for new forms of international contact. Those with access to the internet have a low-cost means of communication, albeit one that is less personal than a phone call. Bill, the "parachute" teen living with his aunt, regularly used e-mail to communicate with friends and with young people from around the world whom he had never metbut he did not email with his own family back in Korea. During Orellana's recent home visit to a Guatemalan family in Pico Union, 12 year-old Adalia displayed an "in box" of email messages from her cousins, as well as samples of cards, photos, and video clips that she received from them. The family had purchased the computer for their children to use for educational purposes; but it had become a useful tool for connecting with family members in Guatemala. The computer was equipped with a video camera that allowed them to send live images to Guatemala, regularly, and at a low cost. (They could not receive images because their family at the other end did not have the video technology.) Adalia's contact with her cousins back home has increased dramatically because of the ease, speed-and thrill—of email; her mother noted, "It's so easy, so fast! Because sometimes we send (an email), and within an hour or two they have written back." Only those families with access to a computer and modem on each end can benefit from the new technology, however, and many families living in rural areas of Central America and Mexico do not own phones, let alone a modem, computer, and internet hookup.

Home video cameras are another form of new technology allowing a more vivid connection between distant family members than was possible in the past. For many families, video has served as an important tool to keep families in touch with one another's lives and to keep transnational social fields alive. (Video images can cross national borders even when the people captured in them cannot.) Orellana attended a funeral service and wake that was videotaped-not to record the memory for future viewing by participants, of course, but to share the experience with relatives back home. But as with phone calls, video images may have emotional costs. Lucia, an eight year-old girl in Pico Union, wouldn't talk to her father for four days after seeing a videotape he made on a trip to El Salvador. The father filmed a daughter (half sister to Lucia), whom Lucia had never met. The video seemed to provoke sibling rivalry that had never before been expressed.

As these examples illustrate, families in Pico Union explore creative ways of staying connected across long distances, and with limited economic resources, although frequency and types of contact vary. Adalia's family, for example, emailed regularly; they traveled to Guatemala once a year for at least several weeks at a time; and they received several visits a year from extended family members. About three fourths of the children with whom we talked had gone with their parents to visit their home countries once or twice, often in response to family emergencies. A smaller group of children had never visited. The implications of these varied kinds and degrees of contact bear further exploration.

\section{Discussion and Conclusion}

Children are involved in family migration processes in ways that are shaped by sociopolitical circumstances, global economic conditions, geographic patterns, historical and political 
relations between countries, available resources, and cultural beliefs and practices. Our intent is not to make fixed claims about the migration experiences of any group, but to illuminate these varied dimensions, and to highlight how children's perceived needs, interests, and desires influence the decisions families make within the constraints of particular circumstances.

Immigrant children, like all children, are, to some extent, dependent on adults for physical, economic, and emotional care. However, just how and in what ways children of different ages and genders are seen as dependent, and how their perceived needs are met, is culturally constructed. Beliefs and practices are, in turn, influenced by material realities, resources, and obstacles. Families may find that a child's physical, emotional, and economic needs conflict, or that they are not able to provide for them in the ways that they would like. ${ }^{4}$ Parents who leave their children behind or send them abroad worry that their children will suffer physically and emotionally in their absence, but they separate from them in order to provide for them in other ways. Transnational families challenge mainstream constructions of "motherhood" (Hondagneu-Sotelo and Avila 1997) and "households" (Olwig 1999), as well as middle class assumptions that all the needs of children can and should be provided by parents in nuclear families based in one community.

In making decisions about leaving kids, bringing them, or sending them back, adults are actively engaged in the process of "developing" their children toward the goals and values they hold for them. Sometimes families may temporarily neglect the needs or presumed needs of their children (or, in the eyes of some observers, appear to be neglectful) in order to open up possibilities for their futures. Some transnational moves involve deliberate, long-term strategies; others represent forced choices based on limited options. Families who are pressed for household survival do not have the luxury to foreground a child's "developmental needs." Families that are divided across national borders, operating with minimal economic resources, do, however, make great sacrifices-including, perhaps, the loss of a certain quality in their own love for their children, and their children's love for them-in order to give their children opportunities, as parents told us, "to come out ahead."

In seeking opportunities for the future of their children, families are also strategizing to improve their collective conditions. The individualistic focus of traditional Western views of child development tends to neglect the collective interests of families and to ignore the tight links that may connect children to larger family networks. The "development" of "parachute children," for example, is closely tied to their deployment as a way of improving a family's future class positions. Transnational arrangements can help families to reposition themselves within a changing global economic order; disrupting class relations that may more rigidly bind families back home. By operating in a transnational sphere, in an historical moment with increased flows of labor and capital around the world, families and individuals create room for maneuvering, and for altering the trajectories that were seemingly laid out at birth.

In this article we have focused on the ways in which children figure in adults' decisions to stay, settle, or return. In most families, adults are the ones who make decisions. But the presence of the children is central to the families' decision-making processes, and children fundamentally shape the nature and course of families' migration experiences. (Children's voices may also weigh in directly; and when their opinions are not invited or respected, they may assert their wills by whining, nagging, complaining, protesting, or refusing to engage with adults' agendas.)

In other work, we are exploring how immigrant children facilitate processes of settlement and community building, for example, through their work as language and cultural brokers (Orellana 2001; see also Valenzuela 1999). We are also examining ways in which processes of immigration help reconfigure both generational and gender relations (Thorne, Orellana, Lam,

4. The needs of different family members may also conflict. Models that assume that households follow a unified strategy in working out immigration projects too easily gloss conflict and differential relations of power (Wolf 1990). The standard division of families into "adults" and "children" overlooks differences between those of different ages and genders, and those with varied sorts of entitlement (such as citizenship), capacities, or skills. 
and Chee forthcoming), sometimes giving more power to children than they had vis-à-vis adults in their home countries. These changing dynamics of power may, in turn, influence families' decisions to stay, settle, or return.

Children may aid and encourage the settlement and assimilation of immigrant families, even while also playing an important role in keeping parents connected to their homelands. This is especially true when an immediate family is split, with some children in each country; in those cases, as others have shown (Olwig 1999; Soto 1987), children serve as social, emotional, and economic "linchpins" for households that span transnational borders. But even when all children live in the U.S., families may maintain ties with the home country for the sake of their children. They may do this for a range of reasons: because they want their children to know and value their relatives, their roots, and their home language; as a way of marking deliberate "difference" from the mainstream U.S. (especially clear in the Yemeni case); because parents want to be able to invoke "transnational disciplining"; or simply to keep open a range of options to provide for their children's varied needs and future possibilities. Finally, parents may sustain ties "back home" because their children ask for, or seek out, such connections.

Scholars who ignore children's presence and participation in processes of migration, framing them as baggage that weighs down adult migrants, neglect a central axis of family migration, and an important reason why families move across national borders and sustain transnational ties. Adult-centered studies of migration also obscure ways in which children actively shape the nature of their families' journeys, the spaces they move in, and their experiences within those social fields. And in shaping those journeys, the children of immigrants shape their own trajectories as well.

\section{References}

¡Aquí Vivimos! Book Project

1993 Aquí Vivimos: Voces de Familias Mexicanas y Centro Americanas en la Ciudad de Los Angeles.

Unpublished manuscript.

Ariès, Philippe

1962 Centuries of Childhood: A Social History of Family Life. New York: Vintage Books.

Arzipe, Lourdes

1982 "Relay migration and the survival of the peasant household." In Toward a Political Economy of Urbanization in Third World Countries, Helen Safa, ed. Delhi: Oxford University Press.

Basch, Linda, Nina Glick Schiller, and Cristina Szanton Blanc

1994 Nations Unbound: Transnational Projects, Postcolonial Predicaments, and Deterritorialized NationStates. Amsterdam: Gordon and Breach Publishers.

Chinchilla, Norma, and Nora Hamilton

1992 "Seeking refuge in the city of angels: The Central American community." In City of Angels, Gerry Reposa and Carolyn Dersch, eds., 84-100. Dubuque, IA: Kendall Hunt Publishing.

Cho, Hae-Joang

1996 "Children in the examination war in South Korea: A cultural analysis." In Children and the

Politics of Culture, Sharon Stephens, ed., 141-168. Princeton, NJ: Princeton University Press.

Daniels, Roger

1990 Coming to America. Princeton, NJ: Harper Collins Publisher.

de la Garza, Roger, Manuel Orozco, and Miguel Baraona

1998 Binational Impact of Latino Remittances. Claremont, CA: Tomas Rivera Policy Center.

Dill, Bonnie Thornton

1988 "Our mother's grief: Racial-ethnic women and the maintenance of families." Journal of

Family History 13:415-431. 
1994 "Fictive kin, paper sons, and compadrazgo: Women of color and the struggle for family survival." In Women of Color in U.S. Society, Maxine Baca Zinn and Bonnie Thornton Dill, eds., 149-169. Philadelphia: Temple University Press.

García Coll, Cynthia, and Katherine Magnuson

1997 "The psychological experience of immigration: A developmental perspective." In International Migration and Family Change: The Experience of U.S. Immigrants, Alan Booth, Ann C. Crouter, and Nancy Landale, eds., 91-132. Mahway, NJ: Lawrence Erlbaum.

Garrison, Vivian, and Carol I. Weiss

1979 "Dominican family networks and United States immigration policy: A case study." International Migration Review 13:264-283.

Georges, Eugenia

1992 "Gender, class, and migration in the Dominican Republic: Women's experiences in a transnational community." Annals of the New York Academy of Sciences 645:81-100.

Guarnizo, Luis E.

1997 "Transnationalism from below: Social transformation and the mirage of return migration among Dominican transmigrants." Identities 4:281-322.

Guarnizo, Luis E., and Michael P. Smith

1998 "The locations of transnationalism." In Transnationalism from Below, Michael P. Smith and Luis E. Guarnizo, eds., 3-34. New Brunswick, NJ: Transaction Publishers.

Guerra, Juan C.

1998 Close to Home: Oral and Literate Practices in a Transnational Mexicano Community. New York: Teachers College Press.

Hamilton, Denise

1993 "A house, cash, and no parents." Los Angeles Times (June 24):A-1.

Harbinson, Sarah F.

1981 "Family structure and family strategy in migration decision-making." In Migration Decision Making, Gordon F. DeJong and Robert Gardner, eds., 225-251. New York: Pergamon Press.

Hirsch, Jennifer S.

1999 "El Norte la mujer manda: Gender, generation and geography in a Mexican transnational community." American Behavioral Scientist 42:1332-1349.

Hondagneu-Sotelo, Pierrette

1994 Gendered Transitions: Mexican Experiences of Immigration. Berkeley: University of California Press.

1995 "Women and children first: New directions in anti-immigrant politics." Socialist Review 25:169-190.

1999 "Introduction: Gender and contemporary U.S. immigration." American Behavioral Scientist 42:565-576.

Hondagneu-Sotelo, Pierrette, and Ernestine Avila

1997 "I'm here, but I'm there': The meanings of Latina transnational motherhood." Gender $\delta$ Society 11:548-571.

James, Allison, and Alan Prout, eds.

1997 Constructing and reconstructing childhoods: Contemporary issues in the sociological study of childhood, 2nd ed. Washington D.C.: Falmer Press.

Kim, D., M. Bae, and Y. Oh

1998 "We have barely adapted . .': Anxious early international students." The Korea Central Daily (April 29):B-3.

Laslett, Barbara, and Johanna Brenner

1989 "Gender and social reproduction." Annual Review of Sociology 15:381-404.

Mahler, Sarah J.

1998 "Theoretical and empirical contributions toward a research agenda for transnationalism. In Transnationalism from Below, Michael P. Smith and Luis E. Guarnizo, eds., 64-99. New Brunswick, NJ: Transaction Publishers.

1999 "Engendering transnational migration: A case study of Salvadorians." American Behavioral Scientist 42:69-719. 
Matthei, Linda M., and Smith, David A.

1998 "Belizian boyz 'n the 'hood? Garifuna labor migration and transnational identity." In Transnationalism from Below. Michael P. Smith and Luis E. Guarnizo, eds., 270-290. New Brunswick, NJ: Transaction Publishers.

Menjivar, Cecelia

1999 "Living in two worlds? Guatemalan-origin children and emerging transnationalism." (Unpublished manuscript.)

Ogbu, John

1989 "Variability in minority school performance: A problem in search of an explanation." Anthropology and Education Quarterly 18:312-334.

Olwig, Karen Fog

1999 "Narratives of the children left behind: Home and identity in globalised Caribbean families." Journal of Ethnic and Migration Studies 25, 2:267-284.

Ong, Aihwa

1999 Flexible Citizenship: The Cultural Logics of Transnationality. Durham, SC: Duke University Press. Orellana, Marjorie Faulstich

2001 "The work kids do: Mexican and Central American immigrant children's contributions to households, schools and community in California." Harvard Educational Review, 7, 3:366-389.

1999 "Space and place in an urban landscape: Learning from children's views of their social worlds." Visual Sociology 14:73-89.

Pedraza, Silvia

1991 "Women and migration: The social consequences of gender." Annual Review of Sociology $17: 303-25$.

Portes, Alejandro, and Min Zhou

1993 "The new second generation: Segmented assimilation and its variants." Annals of the American Academy of Political and Social Sciences 530:74-96.

Ressler, Evertt M., Neil Boothby, and Daniel J Steinbock

1988 Unaccompanied Children: Care and Protection in Wars, Natural Disasters, and Refugee Movements. New York: Oxford University Press.

Rouse, Roger

1992 Making sense of settlement: Class transformation, cultural struggle, and transnationalism among Mexican Migrants in the United States. In Toward a Transnational Perspective on Migration: Race, Class, Ethnicity and Nationalism Reconsidered, N. Glick Schiller, L. Basch, and C. Blanc, eds., 25-52. New York: New York Academy of Sciences.

Ruddick, Sara

1998 "Care as labor and relationship." In Norms and Values, J. C. Haber and M. S. Halfon, eds., 3-25. Totowa, NJ: Rowman and Littlefield.

Rumbaut, Ruben G.

1994 "The crucible within: Ethnic identity, self-esteem, and segmented assimilation among children of immigrants." International Migration Review 28:748-794.

1996 "The new Californians: Assessing the educational progress of children of immigrants." Berkeley, CA: California Policy Seminar (April).

Sassen, Saskia

1998 Globalization and its Discontents: Essays on the New Mobility of People and Money. New York: New Press.

Sienus, Larry, ed.

1992 Between the Lines: Letters Between Undocumented Mexican and Central American Immigrants and their Families and Friends. Hopewell, NJ: The Eco Press.

Soto, Isa Maria

1987 "West Indian child fostering: Its role in migrant exchanges." In Caribbean Life in New York City, Constance R. Sutton and Elsa M. Chaney, eds. New York: Center for Migration Studies of New York.

Stack, Carol B., and Cromartie, John B.

1992 "The journeys of Black children: An intergenerational perspective." In Noneconomic Migration, Patrick C. Jobes, William F. Stinner, and John M. Wardell, eds., 363-383. Lanham: University Press of the Americas. 
Stephens, Sharon

1995 "Children and the politics of culture in 'late capitalism." In Children and the Politics of Culture, Sharon Stephens, ed., 3-48. Princeton, NJ: Princeton University Press.

Swanson, Jon C.

1988 "Sojourners and settlers in Yemen and America." In Sojourners and Settlers: The Yemeni Immigration Experience, Jonathan Friedlander, ed., 49-67. Salt Lake City: University of Utah Press.

Thorne, Barrie

1987 "Re-visioning women and social change: Where are the children?" Gender and Society 1:85-109.

1993 Gender Play: Girls and Boys in School. New Bunswick, NJ: Rutgers University Press.

2001 "Pick-up Time at Oakdale elementary school: Work and family from the vantage points of children." In Work and Family, Rosanna Hertz and Nancy Marshall, eds. Berkeley: University of California Press.

Thorne, Barrie, Marjorie Faulstich Orellana, Wan Shun Eva Lam, and Anna Chee

Forthcoming "Raising children and growing up across national borders: Comparative perspectives on age, gender, and migration." In Gender and U.S. Immigration: Contemporary Trends, Pierrette Hondagneu-Sotelo, ed. Berkeley, CA: University of California Press.

Tienda, Marta, and Karen Booth

1991 "Gender, migration and social change." International Review of Sociology 6:51-72.

Valenzuela, Abel, Jr.

1999 "Gender roles and settlement activities among children and their immigrant families." American Behavioral Scientist 42:720-742.

Wallace, Scott

2000 "You must go home again: Deported gangbangers take over El Salvador." Harpers Magazine (August):47-56.

Walkerdine, Valerie

1984 Schoolgirl Fictions. New York: Verso.

Wolf, Diane L.

1990 "Daughters, decisions and domination: An empirical and conceptual critique of household strategies." Development and Change 21:43-74.

Wong-Fillmore, Lily

1991 "When learning a second language means losing your first." Early Childhood Research Quarterly 6:323-346.

Zelizer, Viviana A.

1985 Pricing the Priceless Child: The Social Value of Children. New York: Basic Books.

Zhou, Min

1997a "Growing up American: The challenge confronting immigrant children and children of immigrants." Annual Review of Sociology 23:62-95.

$1997 \mathrm{~b}$ "Parachute kids' in Southern California: The educational experience of Chinese children in transnational families." Educational Policy 12:682-704. 